\section{Journal of Global \\ Management Sciences}

Vol. 3, $\mathbf{N}^{\circ} 1,2020$

\title{
The Impact of Predatory Publishing in Academic Research: A General Review \\ [El impacto de las publicaciones depredadoras en la investigación académica: Una revisión general]
}

\author{
Carlos E. Linares \\ Midway University, U.S.A. \\ clinares@midway.edu
}

Received: 21 July 2020; Accepted: 17 August 2020; Published: 19 August 2020

\begin{abstract}
Resumen
Los científicos e investigadores de las universidades se han convertido en el objetivo de las revistas depredadoras en los últimos años. Estas revistas falsas utilizan prácticas engañosas para victimizar a los investigadores prometiéndoles una aceptación garantizada de su investigación y asegurando publicaciones tanto en línea como impresas. Existe una cultura persistente en el entorno académico de "publicar o perecer" para ascender en las carreras académicas. Por eso, estas revistas depredadoras se aprovechan de la presión que los académicos tienen que publicar para engañarlas y explotarlas intencionalmente en su beneficio. Esas revistas están motivadas insaciablemente por el dinero. Comercializan sus servicios enviando correos electrónicos a los académicos, animándolos a enviar sus trabajos de investigación a través de ellos. Sin embargo, las presentaciones no son gratuitas; cobran a los autores por servicios que no brindan, como revisión por pares, corrección de pruebas y garantía de calidad. El propósito de esta narrativa es crear conciencia sobre las revistas depredadoras y aumentar el conocimiento de quiénes son para evitar que los artículos científicos de los académicos se pierdan en el limbo para siempre. Además, los académicos deben evitar las consecuencias negativas de publicar sus investigaciones en estas llamadas revistas depredadoras cuando se les anima a través de correos electrónicos a enviar sus publicaciones. Estos editores no solo pueden llevarse el dinero de los científicos o las universidades, sino también la reputación del investigador
\end{abstract}

Palabras clave: Revistas depredadoras, Pseudo-revistas, Revistas oportunistas, Acceso abierto.

\begin{abstract}
Scientists and researchers from universities have become the target of predatory journals over the last few years. These false journals use deceptive practices to victimize researchers by promising them a guaranteed acceptance of their research and ensuring both online and print publications. There is a persistent culture in the academic environment of "publish or perish" to climb the ladder in academic careers. Because of that, these predatory journals take advantage of the pressure's academics have to publish to deceive and exploit them intentionally for their profit. Those journals are insatiably motivated by money. They market their services by sending emails to academicians, encouraging them to submit their research papers through them. However, submissions are not free; they charge the authors for services they do not provide, such as peer-review, proofreading, and quality assurance. The purpose of this narrative is to create awareness about predatory journals and increase the knowledge of who they are to prevent scholars' scientific articles get lost in the limbo forever. Furthermore, academics should avoid the
\end{abstract}




\section{GMS \\ Journal of Global Management Sciences}

Vol. 3, $\mathbf{N}^{\circ} 1,2020$
Copyright @ 2020, CINCADER.

ISSN 2663-0753

DOI: https://doi.org/10.32829/gms.v3i1.170

negative consequences of publishing their research in these so-called predatory journals when they are encouraged through emails to send their publications. Those publishers not only can take the scientist's or universities' money but also the researcher's reputation.

Keywords: Predatory journals, Pseudo-journals, Opportunistic journals, Open Access.

\section{Introduction}

In the 1980s and 1990s, university librarians were struggling with the high subscription costs for publications, and they were canceling their journal subscriptions. This circumstance was affecting the whole world and not only universities in the U.S. The scarce economic resources librarians had made it difficult to obtain the publications they needed. This situation was known as the "serials crisis" because of the reduced budget in libraries, the high cost of academic journal subscriptions, and the incapacity of libraries to bring those costs down (Young, 2009). Borgman (2007, p. 111) stated that universities were paying twice to get the publication they wanted because they pay "once for the salary of their faculty members who did the research and a second time to buy their scholarly products back from the publishers." With the lack of money and no publications, librarians and universities sought new alternatives to get what they needed.

Almost all the scholarly journals were printed-based before the Internet began to play an important role. With the arrival of the Internet and data digitalization in the late 90s, many changes started to be noticed. The concept of open-access (OA) arises around 2000, and suddenly, publishing was accessible to anyone with internet access, and scholarly journals published in the world wide web (www) was available at low costs.

There are numerous definitions of what open-access means; however, its concept is still evolving. Several initiatives were trying to define this concept, such as The Budapest Open Action Initiative, The Bethesda Statement on Open Access Publishing, and The Berlin Declaration on Open Access to Knowledge in the Sciences and Humanities. There are other statements by new groups that contribute to the open-access understanding. Including in those groups are Group of Eight's, Statement on Open Access to Scholarly Information, IFLA Statement on Open Access to Scholarly Literature and Research Documentation, Messina Declaration, Scottish Declaration of Open Access, Washington D.C. Principles for Free Access to Science, and World Summit on the Information Society's Declaration of Principles, Plan of Action (Bailey, 2007).

Suber (2004), a member of the Scholarly Publishing and Academic Resources Coalition (SPARC), developed a definition combining the Budapest, Bethesda, and Berlin Declarations (known as the BBB). He detailed that open access refers to a "free and unrestricted online availability of journal literature, made possible by the convergence of the tradition of scholarly publishing and the technology of the Internet." However, the definition of the Budapest Open Action Initiative is more specific about it. It stated, "is free availability on the public internet, permitting any users to read, download, copy, distribute, print, search, or link to the full texts of these articles, crawl them for indexing, pass them as data to software, or use them for any other lawful purpose, without financial, legal, or technical barriers other than those inseparable from gaining access to the internet itself." (Guedon, 2017).

With the OA and the Internet, the monopoly of unrestricted access to research publications was broke, and a new business model emerged. This new business model was based on e-licensing and the delivery of collections of journals (Shen \& Bjork, 2015). Research institutions now have a repository with a large number of discipline-based and databases such as PubMed Central and BioMed Central. Additionally, this new model eliminates intermediaries (editorial groups) and 
Vol. 3, $\mathrm{N}^{\circ}$ 1, 2020

\section{GMS \\ Journal of Global Management Sciences}

Copyright @ 2020 , CINCADER.

ISSN 2663-0753

DOI: https://doi.org/10.32829/gms.v3i1.170

transferred the editing costs directly from the authors to the publishers (Jimenez-Contreras \& Jimenez-Segura, 2016).

There are three different publication models in the open-access currently in use. These include the Gold Model, distributed to readers without charge, where the publisher charges the author a fee (article processing charge, or APC) once the author's article is accepted for publication. The APC varies from a few hundred to several thousand dollars per article. The highest price is for STEM articles. There is also a Non-APC Golden OA where articles are published on institutions and libraries such as Knowledge Unlatched, Annual Reviews Public Health, or American Journal of Popular Culture (Gunaydin \& Dogan, 2015). Green access is where an author publishes their research in any article and then self-archive a copy in a freely accessible online archive known as a repository. The last open-access model called Hybrid when some articles in a journal are open-access, and others are not (Shen \& Bjork, 2015).

Researchers and librarians very well received the open-access model since its appearance at the beginning of 2000. Unfortunately, one of the negative consequences of this new OA model is the appearance and increase of unscrupulous publishers. These pseudo-publishers take advantage of the conjuncture and ingenuity of many researchers for profit, by requiring authors to pay for publication upfront (APC fees). As said by Shen and Bjork (2015), these publishers are in the business of scholarly publishing with the sole purpose of collecting APCs, providing rapid publication, and undermining the peer review process.

This study will discuss the ethical problems surrounding predatory publishers and the consequences of publishing in these journals. Besides, particularly warn the inexperienced researchers, who have the pressure to publish to be promoted or generate an increase in wages not to be easy prey for these unscrupulous publishers.

\section{Background of Predatory}

Over the last few years, researchers have been cheated by predatory journals in different ways. Predatory journals ask researchers and authors to publish their papers in illegitimate gold OA (author pays) journals charging an article processing charge (APC) for their profit. Jeffrey Beall, then a librarian at the University of Colorado - Denver's Auraria Library, now retired, coined the term "predatory," introducing both publishers and journals. Other words that have been suggested are pseudo-journals (McGlynn, 2013) and opportunistic journals (Greenblatt \& Bertino, 2018).

Between 2008 and 2010, Beall started to notice an increasing number of emails from new publishers and journals soliciting him to submit his research to be published or join their editorial boards. He was fascinated with this new way to attract scholars that he began browsing their websites and gather all the information related to this new type of scholarly publication. Beall realized that these journals and their publishers were not quite what they claimed. With all the data collected, he tracked and categorized them, and observed serious grammar mistakes, substandard websites, and common adjectives in most of them, such as "world," "global," and "international," as part of their names (Butler, 2013a).

He became a whistle-blower with his pioneering work, denouncing all of these for-profit journals and publishers. In 2010, he launched his famous (or infamous) list in his personal blog under the umbrella of Scholarly OA blog (scholarlyoa.com), but just a few authors knew about it. However, at the opening of 2012, his blog began attracting more visitors and gaining attention. The first list had only a few entries with a second list called the "watchlist" ((Beall, 2017). After a while, he realized that "the watchlist was essentially the same as being on the main list." (Beall, 2017, p. 275). The first published list contained only 20 journal titles; by 2013, it grew to 300 . The last update in the Beall's record was in May 2018, including more than 1,600 predatory journals and 


\section{GMS \\ Journal of Global Management Sciences}

Vol. 3, $\mathrm{N}^{\circ}$ 1, 2020
Copyright @ 2020, CINCADER.

ISSN 2663-0753

DOI: https://doi.org/10.32829/gms.v3i1.170

1,200 predatory publishers. On the words of Greenblatt and Bertino (2018), maybe between 2,000 and 8,000 of these journals, publishing annually an average of 400,000 papers per year.

After five years of publishing in his blog, adding more opportunistic journals and publishers to his list, he abruptly shut it down in mid-January 2017. Although the URL was removed from the web and he stopped adding to his list, many librarians still refer to an archived version of the list (beall.weebly.com). The owner of this site (Weebly) decided to be anonymous but does sporadically updates to the list, being the last one in May 2019.

Beall created this list based on his evaluation, which left him utterly vulnerable to the aggressive attacks of these unscrupulous journals. He was the target of these publishers with spiteful commentaries online, frequent harassment and threats of charges, emails sent to his colleagues in the university making false accusations, and other belligerent tactics such as aggravating university officials with letters and emails explaining that he was damaging their reputation. In 2017, he wrote the following "What I learned from predatory publishers is that they consider money far more important than business ethics, research ethics, and publishing ethics and that these three pillars of scholarly publishing are easily sacrificed for profit." (Beall, 2017, p. 275).

After the Beall's lists were taken down, another product was introduced at the 2017 Society for Scholarly Publishing (SSP) meeting (Anderson, 2017). Cabell's International, an organization located in Beaumont, Texas, launched its product, and now access is available for purchase. Its blacklist has more than 12,000 journal titles with another 1,000 under consideration (Ojala, 2019). As mentioned, the whitelist and blacklist are available for organizations and individuals with a budget. A university librarian explained that his university was charged $\$ 57,000$ per year for access; however, this person did not know specified if that quote was for the whitelist, blacklist, or a combination of both (Anderson, 2019).

\section{The modus operandi, and where are they?}

Butler (2013b), mentioned that publishers and journals create websites emulating even the slightest details of the original website. They exhibited the titles of respectable journals, logo, impact factor, address, including the international serial number on their websites. These fake websites are so credible that they have fooled many scholars, sometimes, "victims...contact the authentic journals' editors to ask the status of their work after they transfer the money and do not see their work published in the journals" (Butler, 2013b, p 1). Most of the time, they distribute spam emails to solicit article submissions or to serve in their editorial board as editors. Scientists are asked to pay publication and processing costs, typically between US $\$ 1,800$ - US $\$ 3,000$ either before or after the paper is accepted for publishing. However, this payment did not offer the regular services of a legitime OA journal such as peer-review, proofreading, quality assurance, and extensive exposure.

Many of these pseudo-journals claimed to have their headquarters in London or New York when they are really based in South Asia or West Africa (Beall, 2016). Shen and Bjork (2015) (see figure 1) conducted a study classifying the publishers on Beall's list in terms of their journal size. From 1030 publishers in the starting point, they excluded 64 because they had invalid links. Of the 966 publishers remaining, they found a total of 11,873 journals that published an estimated 420,000 articles in 2014. According to the authors, "most of the publishers are relatively small with less than ten journals, but there are several publishers with large fleets of journals" (p. 3). 


\section{GMS \\ Journal of Global Management Sciences}

Vol. 3, $\mathbf{N}^{\circ} 1,2020$
Copyright @ 2020 , CINCADER.

ISSN 2663-0753

DOI: https://doi.org/10.32829/gms.v3i1.170

\section{CINCADER}

Centre of Research and Training for

Regional Development

Online at www.journals.cincader.org

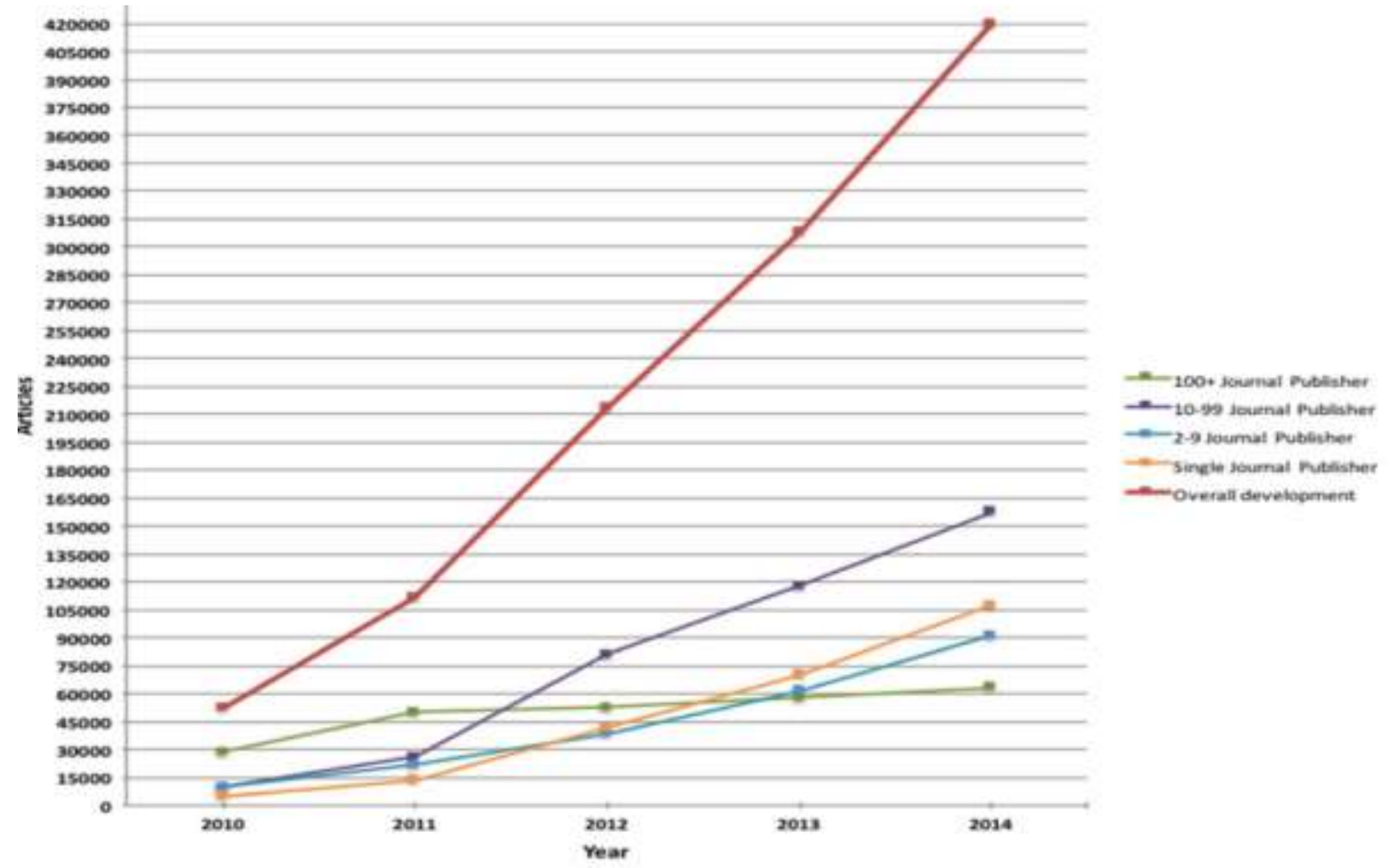

Figure 1. Journal Publishers between 2010 and 2014

Source: Shen \& Bjork (2015)

The geographic distribution of these 966 fake publishers indicated that $27 \%$ are in India, almost $18 \%$ in North America, and $12 \%$ in Asia, with $27 \%$ impossible to determine where they are located. Likewise, the same study described that $35 \%$ of authors are from India, $26 \%$ from Asia (excluding India), 16\% from Africa, and 9\% from North America.

\section{Ethical Issues and Damages}

Predatory journals are actually a difficult problem for honest authors and publishers. The academic literature that has been published has been plagiarized, containing fraudulent information in some cases, and published in no peer-review journals. Ferris and Winker (2017), described several ethical problems in publishing in these journals. Misrepresentation of whom they are, providing names of members of the editorial board who are not even aware they are part of it, fake locations, and lack of indexing and peer review services. Another ethical issue with predatory journals is that they lack archived content, the acceptability of articles of those who have published in predatory journals are questionable. Besides, the academic deception of authors who support and publish through these journals, including those publications in their curriculum - finally, damaging readers' reliability in the research literature (Ferris \& Winker, 2017).

The Bill Gatton College of Pharmacy at East Tennessee State University (ETSU) is an excellent example to illustrate the consequences of publishing in predatory journals, intentionally or not (Pond, Brown, Stewart, Roane, \& Harirforoosh, 2019). The ETSU advertised a position to fill a vacancy in the Department of Pharmaceutical Science. The requirements for this position included an earned Ph.D., teaching experience, and scholarly publications. Between 2017-2018 the search committee recommended nine applicants out of 40 potential candidates, where only 


\section{GMS \\ Journal of Global Management Sciences}

Vol. 3, $\mathrm{N}^{\circ}$ 1, 2020
Copyright @ 2020, CINCADER.

ISSN 2663-0753

DOI: https://doi.org/10.32829/gms.v3i1.170

five were selected for face-to-face interviews. After reviewing the applications, the committee found out that some applicants have published in predatory journals and listed on their CVs serving as board members. The search committee examined more in-deep these applicants and noted that "among 1028 publications, 181 papers (17.6\%) were published in journals that were either referenced on Beall's list... of the 141 editorial boards that were listed on applicants' CVs, $91(64.5 \%)$ were affiliated with publishers of predatory journals" (Pond et al., 2019, p. 13). Also, the authors explained that of the 40 applicants, nine of them had $50 \%$ or more of their publications in predatory journals and three of them more than $80 \%$.

Now, academic institutions are aware of how potentials candidates to fill vacancies in any department, deliberately or not, are publishing in predatory journals or are serving as editors or in the editorial boards with or without their knowledge. The ETSU was not the only case; there are many of them across the country. To maintain the honor as researchers, each author must evaluate conscientiously the journals where they want to publish the article. Besides, when institutions seek to fill a vacancy, it could be announced with a statement indicating that publication or participation in editorial boards in pseudo-journals will qualify the applicant as ineligible.

\section{Conclusions}

- Predatory journals pose a negative impact as well as ethical issues to scientists and academic institutions that are dealing with this concern for several years. Authors, publishers, educational organizations, and editors have an obligation to defend the three pillars of research: business ethics, research ethics, and publishing ethics. Scientists must have the ability to distinguish between fraudulent and trustworthy journals and avoid publishing in those cheats. Furthermore, authors should forestall the enticements and disregard the emails they receive from predatory journals inviting them to publish or serving as editors or in the editorial boards. Finally, authors must protect their work and themselves from predatory journals that are looking for your article and your money.

- Finally, it is recommended that authors avoid publishing in such journals or citing works that have dubious provenance. Besides, ethics committees should reject research based on articles published in predatory journals, and journal editorial committees should require authors to delete all corresponding references to such publications. Articles that see the light in predatory journals has increased exponentially, so it is an arduous task to report these illegal publishers. There are other types of strategies, perhaps more expensive, that allow avoiding this dangerous activity that can be found in other works written on the subject.

\section{References}

Anderson, R. 2019. Cabell's predatory journal blacklist: An updated review [Online forum comment]. $\quad$ https://scholarlykitchen.sspnet.org/2019/05/01/cabells-predatory-journalblacklist-an-updated-review/

Anderson, R. 2017. Cabell's new predatory journal blacklist: A review. The Scholarly Kitchen. https://scholarlykitchen.sspnet.org/2017/07/25/cabells-new-predatory-journal-blacklistreview/

Beall, J. . 2016, Dangerous predatory publishers threaten medical research. Journal of Korean Medical Science31:1511-1513. 


\section{GMS \\ Journal of Global Management Sciences}

Vol. 3, $\mathrm{N}^{\circ}$ 1, 2020
Copyright @ 2020, CINCADER.

ISSN 2663-0753

DOI: https://doi.org/10.32829/gms.v3i1.170

Beall, J. 2017, What I learned from predatory publishers. Research Integrity Corner: Special issue on predatory journals. Biochemia Medica. 27(2):273-278

Beall's list all predatory journals and publishers (n.d.). Retrieved from https://bealllist.weebly.com/ Bailey, C. W. 2006, What is open access?, http://digital-scholarship.org/cwb/WhatlsOA.pdf

Borgman, C. L. 2007. Scholarship in the digital age: Information, infrastructure, and the Internet. Cambridge, MA: The MIT Press.

Butler, D. 2013a, The dark side of publishing. Nature: The Future of Publishing. Vol. 495, 433435.

Butler, D. 2013b, Sham journals scam authors. Con artists are stealing the identities of real journals to cheat scientists out of publishing fees. https://www.nature.com/news/shamjournals-scam-authors-1.12681

Ferris, L. E. \& Winker, M. A. 2017, Ethical issues in publishing in predatory journals. Research integrity corner: Special issue on predatory journal. Biochemia Medica. 27(2):279-284.

Guedon, J-C. 2017. Open access: Toward the Internet of the mind. Budapest Open Access Initiative. https://www.budapestopenaccessinitiative.org/open-access-toward-the-internetof-the-mind

Greenblatt, D. J. \& Bertino, J. S. 2018, Opportunistic journals in the clinical pharmacology space: A policy statement from the publications and public policy committees of the American College of Clinical Pharmacology. The American College of Clinical Pharmacology. 7(4):353-357.

Gunaydin, G. P. \& Dogan, N. O. 2015, A growing threat for academicians: Fake and predatory journals. The Journal of Academic Emergency Medicine. 14: 94-96

Jiménez-Contreras, E. \& Jiménez-Segura, J. J. 2016, Predatory Journal, a new scientific epidemic. Science and Nursing. 12(2):7-12

McGlynn, T. 2013. The evolution of pseudo journals. Dominguez Hill, CA: Small Pond Science.

Ojala, M. 2019, The impact of predatory publishing on business research. The Dollar Sign, 5860.

Pond, B. B., Brown, S. D., Stewart, D. W., Roane, D. S., \& Harirforoosh, S. 2019, Faculty applicants' attempt to inflate CVs using predatory journals. American Journal of Pharmaceutical Education. 83(1):12-14.

Potential predatory scholarly open-access journals. N.d. https://beallslist.net/standalone-journals/

Shen, C. \& Bjork, B. 2015, Predatory open access: A longitudinal study of article volumes and market characteristics. BMC Medicine. 13:230

Suber, P. 2004. Praising progress, preserving precision. SPARC Open Access Newsletter No. 77. http://legacy.earlham.edu/ peters/fos/newsletter/09-0204.htm\#FEFF00700072006F00670072006500730073

Young, P. 2009. The serials crisis and open access. A white paper for the Virginia Tech Commission of Research. https://scholar.lib.vt.edu/faculty_archives/YoungP/OAwhitepaper.pdf 